\title{
Tributes to Jim Collinge retiring Director of the Stout Research Centre
}

\section{A deep commitment}

\section{W.H. OLIVER}

Convenor, Stout Centre Advisory Board

My impression of the essential character of Jim Collinge as Director of the Stout Centre can be summed up in one word - solicitude. Solicitude for the well-being of the Centre as an institution, for the work and goals of its fellows and residents, and for the interests of its constituency in the university and the city.

His work in and for the Centre was informed by a deep commitment to its purposes, and more so for being evidenced more typically by actions than words. Both as a professional educationalist and as a man of wide sympathies and interests, he believed in bringing intellectual and artistic activities, and their practitioners, together. Quite as important he knew what he was doing: I have heard him talk as convincingly of music and literature as of social science research. I know, from talking to Centre residents, that they valued both his appreciation of their work and his care for their well-being.

Quite often, and I hope often enough to bring him lasting satisfaction, this solicitude was rewarded by, say, a book published or a seminar or a session of a conference that really came off. But it needs to be recorded that frequently it brought disappointment, usually when 'the university', as represented by one or other of its many bits and pieces, paid no heed at all to the Centre's activities, even when they were close to, say, a department's own programme. Once, in fact, a department wholly absent from such a seminar put in a request for a repeat performance in its own premises. Of course, officially and in fact, the University does value the Centre - and so it should and has continued to support it (perhaps a shade meagrely?) in difficult times.

By now there will be places of learning in the world where Victoria is known as the home of the Stout Centre. But the University, especially the decision makers and the resource allocators, should also reflect upon their good luck in finding two directors, with a third waiting in the wings, ready to take on, and to take seriously, an onerous and demanding as well as a rewarding task. I know that Jim, like Jock Phillips before him, kept up a heavy teaching load and sacrificed his research to the Centre - that is, to

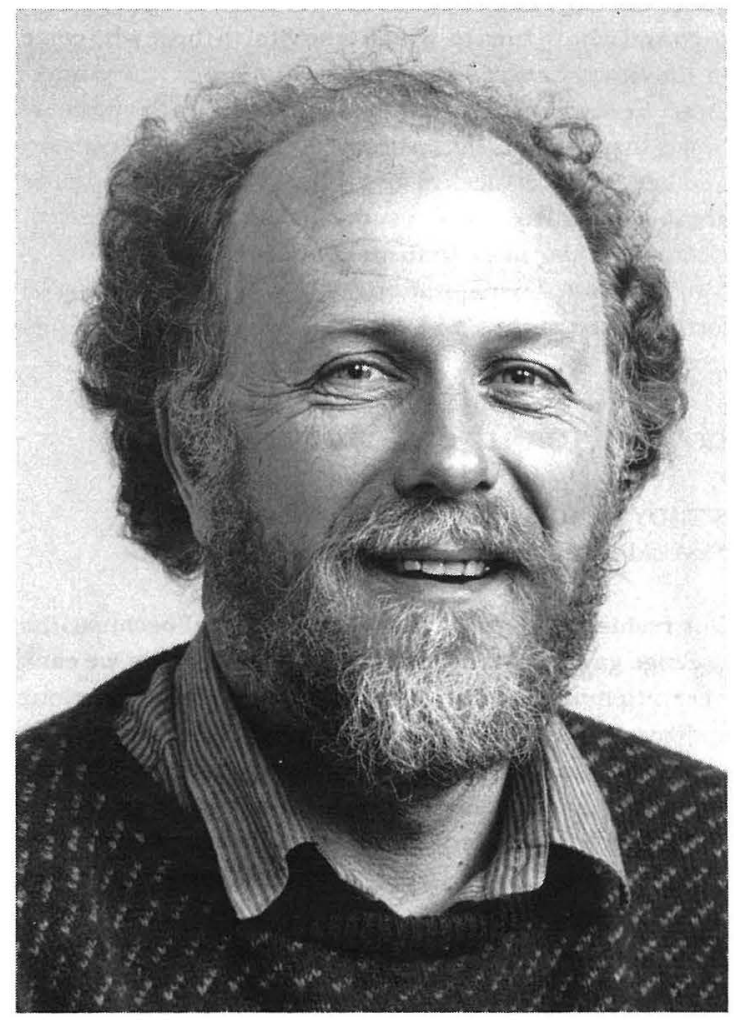

the University. I know, too, that they are people who would not lightly surrender research and writing. The Centre's (and the University's) luck is holding for a third director's term. In that period a good deal of attention should be paid to the prospect that one day the luck will run out.

My time as convenor of the Advisory Board, now also drawing to a close, has been enriched by working with Jim Collinge. I am among the many who are glad to have a chance to offer him their thanks and their good wishes.

\section{With humane concern}

\section{Winifred Bauer}

J.D. Stout Research Fellow 1990

Jim has an apparently inexhaustible supply of enthusiasm 
for all the research that is undertaken at the Centre, and an unfailing cheerfulness and humour which are extremely supportive during research which is often, perhaps by its very nature, unproductive, frustrating or routine. He is equally ready to share the elation that comes with goals achieved or problems solved. He is a wonderful facilitator of research, ready to ensure that no petty rules get in the way, and to share his wide knowledge of where to go and who to turn to, which is so vital to those who come to the Stout Centre from outside. He is genuinely interested in and knowledgeable about a far wider range of topics than most of us can boast, and the humane concern and interest he evinces in all who pass through the Centre are in no small measure responsible for its achievements. He has been far more than an administrator; he has been a great friend and inspiration to all who have had the good fortune to be at the Stout Centre during his Directorship.

\section{Loyalty to our endeavours}

\section{WENDY POND}

\section{Ex-resident and 1992 Stout Fellow}

Our residence at the Stout was exceptional because Jim Collinge gave us his support to accomplish what we each were attempting to do. He was unfailingly loyal to our endeavours. He would join our discussions, where his humanitarianism and breadth of knowledge gave stability to our vision and generated harmony amongst us. At the Stout people worked with passion, rather than amibition.

\section{No idiosyncratic whim}

\section{PETER DOWNES}

Theatre and opera historian

Although friends had assured me that my residency at the Stout Centre would be an enjoyable and rewarding experience, I have to admit to a certain amount of apprehension when I first arrived. I suspected that my particular historical subject - a largely forgotten juvenile comic opera company - might be of singular unimportance when compared with other matters being researched at the Centre; that it was, perhaps, little more than an idiosyncratic whim. How wrong I was! The warmth, understanding and appreciation of my research project shown by Jim immediately reassured me. His own wide horizons easily encompassed my enthusiasm for New Zealand's early theatrical history and it soon became obvious that this attitude was reflected throughout the Centre as a whole.

When the time came to leave (albeit reluctantly), Jim's reassuring words that I would always be welcome to visit the Centre, no matter what the reason, have proved to be unequivocally true. Neither did the influence of the Centre on my work end on that day of departure. It is still being felt. Subsequent involvement in seminars, conferences and other projects - such as the book which Adrienne Simpson and I have recently completed writing together can be traced directly to contacts encouraged and developed by Jim during my time there.

So Jim, on your departure from the Centre, I would like to thank you whole heartedly for your continuing support and interest and to wish you well in the future.

\section{Enlightened working environment}

\section{ADRIENNE SIMPSON \\ National Library Fellow}

Within my first week at the Stout Centre I realised my residency there would be a special experience. The warmth of Jim's greeting and the ready understanding and enthusiasm he showed for my research projects came as a welcome tonic to someone who had previously struggled on without the status that comes from academic acceptance in New Zealand.

Before long I found that the whole Centre was imbued with Jim's own large-minded attitude. Residents undertaking topics so disparate that no point of mutual contact seemed possible ended up finding common ground. Friendships were formed, joint projects initiated. The lunchtime get-togethers were a source of amusement, mental stimulation and information. Research proceeded apace in the most enlightened working environment I had yet encountered.

The benefits of my time at the Stout Centre are still accruing through the contacts made there. First came an invitation from Charlotte Macdonald to contribute to The Book of New Zealand Women. Through Jim's agency, Peter Downes and I discovered the total compatability of our research interests and attitudes, and together we have just finished writing a book, Southern Voices. Now I am working with Anne Else on her Historic Branch publication Women Together. Along the way there have been seminars and conferences and the chance to get to know many interesting people, some of whom have now become good friends.

I doubt if there is a greater compliment than to say, of someone, that they changed your life for the better. Thank you Jim, for everything. 